fully. The licence for development in Great Britain is held by Messrs. W. J. Fraser and Co., Ltd., of Dagenham, Essex.

\section{Norwegian Arctic Research}

IT was some ten years ago that the Norwegian Govermment, having acquired by treaty the sovereignty of Spitsbergen, instituted a department to deal with the scientific exploration of Spitsbergen, Bear Island and other arctic regions, including areas outside Norwegian jurisdiction. This department, Norges Svalbard-og Ishavs-Undersökelser, under the direction of Dr. A. Hoel, has now published a record of the ten years of its activity (Skrifter om Svalbard og Ishavet, No. 73). Earlier Norwegian work was recounted in a previous publication (No. 1, loc. cit; 1929). Almost every summer expeditions have been at work in Spitsbergen and East Greenland and occasionally in other islands, as Jan Mayen, Bear Island and White Island. In Svalbard (Spitsbergen, North-East Land, Bear Island, etc.) $560 \mathrm{sq}$. km. have been mapped on the land and 40,000 sq. $\mathrm{km}$. from the air, and in East Greenland 9,200 sq. km. and 30,000 sq. $\mathrm{km}$. In addition, large areas of the arctic seas have been charted and much oceanographical work accomplished. But no aspect of research has been overlooked, and the department has even erected naviga. tion beacons and lights and introduced the musk-ox and the arctic hare to Spitsbergen. Winters have been used for working up results, and already the publications of the department number over seventy. The greater part of the cost is met by a State grant, but private contributors also help. The volume makes a fine record of careful scientific work.

\section{Electrical and Allied Industries Research Association}

THE seventeenth annual report of the British Electrical and Allied Research Association (E.R.A.) proves that the research scientific worker is becoming indispensable to the industry. It is his work that enables the producer to acquire new principles, data and methods which he can embody in his technique and products. The producer passes these benefits on to the distributor, and finally the consumer derives benefits from greater efficiency, trustworthiness and utility. The work enables the industry to gain substantial immunity from breakdowns and the consequent and ever-present risk of black-outs and extensive damage. The activities of the Association are expanding very satisfactorily. Nearly half the research work of the E.R.A. is now conducted by its own staff. Its success is built up largely upon the gratuitously given labours of its eighty committees comprising about 500 voluntary workers. It carries out researches in co-operation with many scientific and engineering institutions. The principal income of the Association consists of the following annual grants: Department of Scientific and Industrial Research, $£ 24,500$; electricity supply undertakings, $£ 32,932$; manufacturers, $£ 19,737$. In addition, the Institution of Electrical Engineers gives $£ 1,000$ and so also does the B.B.C. The accounts show a surplus for the year of $£ 13,500$ after transferring $£ 5,000$ to the reserve account, but it is pointed out that practically all this sum is already required in connexion with particular researches in hand and is not available for next year's commitments. The Department of Scientific and Industrial Research and other important contributors are urging the Association to establish a more adequate reserve.

\section{The Belfast-Stranraer Telephone Cable}

IN 1853, the British and Irish Magnetic Telegraph Company laid a cable between Port Patrick and Donaghadee. This cable proved to be successful and was one of the forerunners of the Atlantic cable in laying which Lord Kelvin played a leading part. Until last year, the telephone and telegraph traffic had been carried by four telegraph cables laid in 1870, '79, '88 and '93 for telegraph working but afterwards converted to telephone working, and a 'continuously-loaded' cable made in 1921. In addition, a loaded cable connects Blackpool to the Isle of Man and thence to Ballyhornan, Northern Ireland. These cables were made by Siemens Brothers and Co., Ltd., and its associated company, Submarine Cables, Ltd., which claim to be the only British organization that undertakes the design, manufacture and installation of all types of submarine and land cables as well as the necessary carrier-current equipment. In the Engineering Supplement to Siemens Magazine of January a description is given of two more submarine cables completed last September, their opening coinciding with a special low charge for calls carried by submarine cable to Northerm Ireland. As each of these cables can carry four calls simultaneously, there are eight circuits available to help carry the increased traffic brought about by the tariff reduction. It is possible to increase further the carrying capacity by the addition of more carrier equipment. One of the two new cables serves for transmission from Belfast to Stranraer and the other cable for transmission in the opposite direction. In addition to the submarine cables, there is a radio link connecting Ballygomartin, near Belfast, and Port Patrick.

\section{The New Commonwealth Society}

The annual report of the New Commonwealth Society for the year ended September 30, 1937, refers to considerable progress in the development of international sections, new groups or sections having been formed in the United States, Austria and Czecho. slovakia, and arrangements made for the Swiss Europa Union to perform the functions which would otherwise be carried on by a Swiss Section of the Society. The existing groups in Germany and Hungary have been considerably developed, and development in other countries during the period has to some extent outpaced the progress of the British section. Disappointing results have followed the introduction of facilities for the enrolment of group associate members, but the first international conference organized by the Society, held at Pontigny, August 13-23, was an outstanding success, as was a Now Commonwealth Society Youth Camp at Llandinan in August, which included German, Dutch, Czechoslovakian, Norwegian, Hungarian, Greek, Swiss and British representatives. Four new pamphlets 